Journal of Invertebrate Pathology

November 2017, Volume 150, Pages 45-53

http://dx.doi.org/10.1016/i.jip.2017.09.007

http://archimer.ifremer.fr/doc/00399/50997/

(c) 2017 Elsevier Inc. All rights reserved.
Achimer

http://archimer.ifremer.fr

\title{
Haemocytes from Crassostrea gigas and OsHV-1: A promising in vitro system to study host/virus interactions
}

\author{
Morga Benjamin ${ }^{1,{ }^{*}}$, Faury Nicole ${ }^{1}$, Guesdon Stephane ${ }^{2}$, Chollet Bruno ${ }^{1}$, Renault $\operatorname{Tristan}^{3}$
}

${ }^{1}$ Ifremer, RBE-SG2M-LGPMM, Station de La Tremblade, Avenue de Mus de Loup, F-17390 La Tremblade, France

2 Ifremer, ODE-LERPC, Station de La Tremblade, Avenue de Mus de Loup, F-17390 La Tremblade, France

${ }^{3}$ Ifremer,PDG-RBE, Centre de Nantes, Rue de I'lle d'Yeu, F-44311 Nantes, France

* Corresponding author : Benjamin Morga, email address : benjamin.morga@ifremer.fr

\begin{abstract}
:
Since 2008, mass mortality outbreaks associated with the detection of particular variants of OsHV-1 have been reported in Crassostrea gigas spat and juveniles in several countries. Recent studies have reported information on viral replication during experimental infection. Viral DNA and RNA were also detected in the haemolymph and haemocytes suggesting that the virus could circulate through the circulatory system. However, it is unknown if the virus is free in the haemolymph, passively associated at the surface of haemocytes, or able to infect and replicate inside these cells inducing (or not) virion production. In the present study, we collected haemocytes from the haemolymphatic sinus of the adductor muscle of healthy $C$. gigas spat and exposed them in vitro to a viral suspension. Results showed that viral RNAs were detectable one hour after contact and the number of virus transcripts increased over time in association with an increase of viral DNA detection. These results suggested that the virus is able to initiate replication rapidly inside haemocytes maintained in vitro. These in vitro trials were also used to carry out a dual transcriptomic study. We analyzed concomitantly the expression of some host immune genes and 15 viral genes. Results showed an up regulation of oyster genes currently studied during OsHV-1 infection. Additionally, transmission electron microscopy examination was carried out and did not allow the detection of viral particles. Moreover, All the results suggested that the in vitro model using haemocytes can be valuable for providing new perspective on virus-oyster interactions.
\end{abstract}




\section{Graphical abstract}

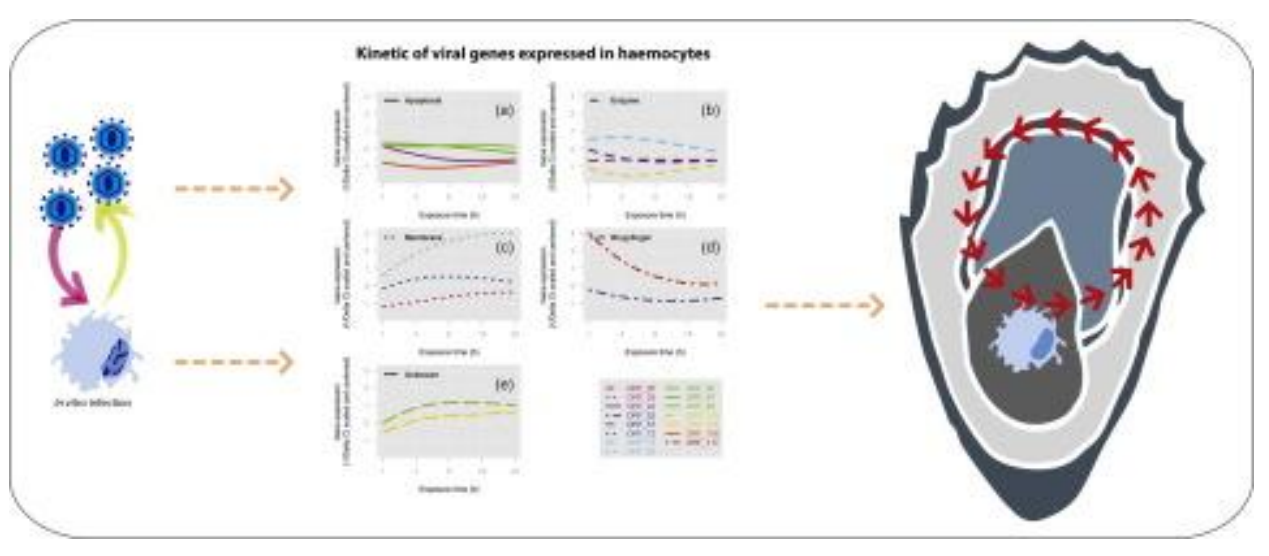

\section{Highlights}

- This study is the first to show that OsHV-1 can initiate viral replication in haemocytes following an in vitro contact. The results showed that there were differential patterns of expression of viral genes over time. Our results open new ways of research in order to explore OsHV-1 pathogenesis. Haemocytes are critical to innate immunity and the virus evolved to perturb host defence. 
59 Ostreid herpesvirus type 1 (OsHV-1), the causative agent of a disease producing major economic

60 losses in the global Pacific oyster industry, is a member of the family Malacoherpesviridae from the

61 order Herpesvirales (Le Deuff and Renault, 1999; Davison et al., 2005, Davison et al., 2009). OsHV-1 is

62 a large enveloped virus that infects several bivalve species (Ostrea edulis, Pecten maximus, Ruditapes

63 philippinarum) (Arzul et al., 2001a, Arzul et al., 2001b, Renault et al., 2001). Two OsHV-1 genotypes

64 were initially reported in France, the reference type and a variant referred to as OsHV-1 Var (Arzul et

65 al., 2001b and Renault et al., 2001). The presence of a third genotype, termed $\mu$ Var (for

66 "microvariant"), has been reported in France since 2008 in association with mass mortality outbreaks

67 among French and European C. gigas (Segarra et al., 2010, EFSA 2010). Additional microvariants have

68 been also reported since 2010 in New Zealand and Australia during mass mortality events affecting

69 the Pacific oyster there (Jenkins et al., 2013; Keeling et al., 2014; Paul-Pont et al., 2013, 2014 ;

70 Renault et al., 2012),

71 Control of OsHV-1 infection is considered as a key element to maintain the competitiveness and to

72 increase the sustainability of the oyster industry. However, Pacific oysters like other marine molluscs

73 present unique challenges in terms of health management (Renault, 2012). Strategies like

74 vaccination that are currently used for other farmed animal species such as cattle and fish cannot be

75 directly applied to Pacific oysters to protect them against the viral infection. A better understanding

76 of interactions between the Pacific oyster and the virus may, however, reveal applicable and

77 promising approaches to limit the harmful effects of these pathogens.

78 Early work with experimental infections results suggested that infective OsHV-1 particles could first

79 enter the oyster host thought the digestive gland and the haemolymphatic system (Schikorski et al.,

80 2011a). Virus particles could then be transported by haemolymph to the different organs before

81 beginning an intense replication phase producing development of associated disease in target tissues 
82 including mantle and gills (Schikorski et al 2011a, Corbeil et al., 2015, Segarra et al, 2016). These

83 results opened new perspectives to study virus-oyster interactions.

84 Segarra et al. (2014a) recently developed a new tool to study the viral replication using a real time

85 RT-PCR. They monitored expression of 39 OsHV-1 mRNAs in Pacific oyster spat (in mantle as a well-

86 identified target organ) during an experimental infection at $0,2,4,18,26$, and $42 \mathrm{~h}$ post-injection. As

87 early as $2 \mathrm{~h}$ post-injection some OsHV-1 mRNAs were detected and by $18 \mathrm{~h}$ post-infection all selected

88 ORFs were expressed. Additionally, Corbeil et al (2015) developed an in situ hybridization technique

89 allowing the detection of viral mRNA on histological sections and demonstrated the presence of viral

90 mRNA in different tissues including the mantle.

91 Although haemocytes (the circulating cells present in haemolymph) play a key role in the immune

92 response of molluscs (Fisher, 1986), few studies have investigated the immune response of $C$. gigas

93 haemocytes against the virus OsHV-1 (Renault et al, 2011). Renault et al. (2011) explored the the

94 haemocyte's response after in vitro contact with OsHV-1 using suppressive substractive hybridization

95 in order to identify candidate genes involved in the host response to the viral infection. That study

96 identified for the first time genes that could be involved in an interferon-like pathway, such as the

97 IFI44 gene. Results were confirmed in various following studies (Green et al., 2015, Segarra et al., 2015). Another study found haemolymph from C. gigas to possess antiviral activity associated with the major haemolymph protein, cavortin (Green et al., 2014a, Green et al., 2014b). These data collectively show that the haemolymph and the haemocytes play a key role in the OsHV-1 infection. However, no study has yet directly investigated the replication of the virus in the haemocytes from $C$. gigas.

The main objective of the present study was to provide knowledge on OsHV-1 entry into haemocytes and viral replication in such cells after a viral challenge in vitro in haemolymph drawn from the adductor muscle of $C$. gigas spat. The kinetics of viral gene expression were also assessed, as already reported for vertebrate herpesviruses, with examination of early, intermediate early and late gene 
expression. Transmission electron microscopy examination was used to search the in vitro-

108 challenged haemocytes for the presence of viral particles.

109 This use of hemocytes in vitro experiment represents a novel approach to the study of an important

110 contemporary problem in oyster health, and our study yielded fresh insight into the nature of the

111 interaction between the virus and its oyster host. The objective of this work is to demonstrate

112 whether haemocytes can be infected with the OsHV-1 virus.

1142 Material and methods

\section{$116 \quad$ 2.1 Pacific cupped oysters}

117 Pacific cupped oysters, C. gigas, were produced in March 2014 at Ifremer hatchery in Argenton, 118 Brittany, France. Oysters were then reared at Ifremer facilities in Bouin, Vendée, France until 119 September 2014 when the study began. Oysters 9 months old with an average size of $5 \mathrm{~cm}$ were 120 used for this study.

\section{2. 2. Haemolymph collection}

123 Haemolymph was withdrawn from the adductor muscle sinus of oysters using a 1-ml syringe 124 equipped with a needle $(0.40 \mathrm{~mm} \times 90 \mathrm{~mm})$. To eliminate debris the haemolymph samples were 125 filtered through $60-\mu \mathrm{m}$ nylon mesh and held on ice to limit cell aggregation. The volume of 126 haemolymph collected from each oyster was approximately 0.5 to $1 \mathrm{~mL}$. Samples were pooled, and

127 haemocyte counts were performed using a Malassez cell. Haemocyte concentration was adjusted to $1281.10^{6}$ cells $\mathrm{ml}^{-1}$ using $0.22 \mu \mathrm{m}$-filtered artificial sea water. 


\subsection{OsHV-1 suspension}

131 Initial tissue homogenates were prepared using ten experimentally infected animals as previously 132 reported (Schikorski et al., 2011a). Oysters were opened by removing the upper valve. Gills and 133 mantle of these animals were then dissected and pooled together in a 50-mL sterile tube. All 134 subsequent dilutions were made using $0.22 \mu \mathrm{m}$-filtered artificial seawater (ASW). The total mass of 135 tissues was weighed and 10 volumes of $0.22 \mu \mathrm{m}$-filtered ASW were added to the tube $(9 \mathrm{~mL}$ of 136 seawater per $\mathrm{g}$ of tissues). Tissues were then homogenized on ice using an Ultraturax mixer $(3 \times 5 \mathrm{~s})$. 137 After centrifugation $\left(1000 \mathrm{~g}, 5 \mathrm{~min}, 4^{\circ} \mathrm{C}\right)$, supernatant was placed in a new tube and diluted by 138 addition of 4 volumes of $0.22 \mu \mathrm{m}$-filtered ASW. Finally, the clarified tissue homogenate was filtered 139 consecutively in sterile conditions using syringe filters at $5-\mu \mathrm{m}, 2-\mu \mathrm{m}, 0.45-\mu \mathrm{m}$ and $0.22-\mu \mathrm{m}$ pore 140 sizes (Millipore, Billerica, USA).

142 Control, OsHV-1-free tissue homogenate. To produce control, virus-free homogenate, the protocol described above was applied to oysters found to be negative for the presence of OsHV-1 DNA by real time PCR.

\subsection{Experimental design}

147 Haemocytes $\left(1 \times 10^{6}\right.$ cells $\left.\mathrm{mL}^{-1}, 5 \mathrm{~mL}\right)$ were incubated with OsHV-1 suspension $\left(2.5 \mathrm{~mL}, 10^{5} \mathrm{OsHV}-1\right.$ 148 copies/ $\mu \mathrm{L}$ ) under low agitation at $19^{\circ} \mathrm{C}$ and analysed after $1,4,8,18$ and $24 \mathrm{~h}$ of in vitro virus 149 exposure. The control consisted of haemocytes $\left(1 \times 10^{6}\right.$ cells $\left.\mathrm{mL}^{-1}, 5 \mathrm{~mL}\right)$ incubated in presence of oyster tissue homogenate considered to be OsHV-1 free $(2.5 \mathrm{~mL}$, see above). The whole experiment

151 was carried out twice in duplicate. To all samples, $350 \mu \mathrm{L}$ of antibiotic mix was added with $4 \mathrm{mg} \mathrm{mL}^{-1}$ 
152 streptomycin, $11.6 \mathrm{mg} \mathrm{mL}^{-1}$ penicillin, $5.1 \mathrm{mg} \mathrm{mL}^{-1}$ neomycin, $3.3 \mathrm{mg} \mathrm{mL}^{-1}$ erythromycin, and $0.1 \mu \mathrm{L}$ $153 \mathrm{~mL}^{-1}$ nystatin.

\subsection{DNA extraction from haemocytes}

Haemolymph $(7.5 \mathrm{~mL})$ was centrifuged for $10 \mathrm{~min}$ at $1500 \mathrm{~g}$, and DNA was extracted from the

157 haemocyte pellet. DNA extraction was performed using a QIAamp Tissue Mini Kit (QIAgen) according 158 to the manufacturer's protocol.

\subsection{OsHV-1 DNA quantification}

161 Real time quantitative PCR was performed in duplicate using a Mx3005P Thermocycler sequence

162 detector (Agilent). Amplification reactions were each performed in a total volume of $20 \mu \mathrm{L}$. Each well

163 contained $5 \mu \mathrm{L}$ DNA from sea water or $5 \mu \mathrm{g}$ DNA total from oyster mantle, $10 \mu \mathrm{L}$ of Brilliant III Ultra-

164 Fast SYBR ${ }^{\oplus}$ Green PCR Master Mix (Agilent), $2 \mu \mathrm{L}$ of each primer OsHVDP For (forward) 5'-

165 ATTGATGATGTGGATAATCTGTG-3' and OsHVDP Rev (reverse) 5'-GGTAAATACCATTGGTCTTGTTCC-3'

166 (Webb et al., 2007) at the final concentration of $550 \mathrm{nM}$ each, and $1 \mu \mathrm{L}$ of distilled water. Real time

167 PCR cycling conditions were as follows: $3 \mathrm{~min}$ at $95^{\circ} \mathrm{C}$ followed by 40 cycles of amplification at $95^{\circ} \mathrm{C}$

168 for $5 \mathrm{~s}$ and $60^{\circ} \mathrm{C}$ for $20 \mathrm{~s}$. The results were expressed as a Log 10 of virus OsHV-1 copy number of viral

$169 \mathrm{DNA} / \mu \mathrm{L}$ of DNA extract.

170 OsHV-1 quantification data were analyzed with XLSTAT-Pro 2014.5 .03 software (Addinsoft; Paris,

171 France). Results were expressed as means \pm standard error. A two-way analysis of variance (ANOVA)

172 followed by Fisher post-tests were used to analyze differences between means of virus DNA amounts

173 (DNA copy number) quantified during the kinetic experiment. 


\subsection{Total RNA extraction}

176 Total RNA was extracted using TRIZOL $^{\circledR}$ Reagent $^{\text {TM }}$ (Ambion ${ }^{\circledR}$ ) according to the manufacturer's

177 recommendations. Total RNA was treated with Turbo $^{\text {TM }}$ DNAse $\left(\right.$ Ambion $\left.^{\circledR}\right)$ to remove genomic DNA.

178 After DNAse treatment, a second RNA extraction using TRIZOL was carried out. RNA quality and

179 quantity were determined using a NanoDrop 2000 (Thermo Scientific). First-strand cDNA synthesis

180 was performed using the SuperScript ${ }^{\circledR}$ III First-Strand Synthesis System (Invitrogen) with 500 ng of

181 RNA used. A No RT (No Reverse Transcription) was performed after RNA extraction using real time

182 PCR in order to control absence of oyster and/or virus genomic DNA using EF primers (Table 1) and 183 the OsHVDP For/OsHVDP Rev primers.

\subsection{OsHV-1 gene expression}

To study viral gene expression, 15 viral genes were selected based on protein functions or structures

187 of related proteins among the 124 ORFs of OsHV-1 (Davison et al., 2005). These belonged to 5 groups

188 or families of genes. Among genes selected, 11 were previously studied by Segarra et al. (2015a).

189 Four genes were added for this study (Table 1). Real-time quantitative RT PCR was used to study the expression of the 15 viral genes using the previously described protocol with $5 \mu \mathrm{L}$ of cDNA dilution $(1 / 30)$ instead of genomic DNA. Elongation factor alpha (EF1 alpha) was chosen to normalize the viral gene expression. The $\mathrm{Ct}$ difference between the viral gene and EF1 alpha provided the relative expression level of the viral gene.

194 Viral gene expression levels were calculated for each sample with formula:

\section{Delta $\mathrm{Ct}=\mathrm{Ct}$ ORF-Ct Elongation factor alpha}

196 The levels of gene expression (delta $\mathrm{Ct}$ ) of the initial array data were transformed by the inverse

197 function $1 /$ delta $C t$. This allowed easier interpretation thanks to positive link between this indicator 
198 (1/delta $\mathrm{Ct})$ and the level of gene expression. Discrimination of gene expression was based on the 199 results of a principal component analysis (PCA). This analysis was based on the average of replicates 200 per exposure time (centered and reduced). This data configuration by exposure time (case of PCA) 201 allowed determination of the relative increase of the gene expression between treatments for each Haemocyte suspensions $\left(110^{6}\right.$ cells) were centrifuged at $500 \mathrm{~g}$ for $8 \mathrm{~min}$ at $4^{\circ} \mathrm{C}$ and supernatant was removed. Samples were fixed in $3 \%$ glutaraldehyde solution for 1 day at $4^{\circ} \mathrm{C}$. Cells were washed 3 220 times with $0.4 \mathrm{M}$ cacodylate buffer and post-fixed with a solution of $1 \%$ osmium tetroxide for $1 \mathrm{~h}$ at

2214 C. Cells were washed twice again in $0.4 \mathrm{M}$ cacodylate buffer. After dehydration in successive baths

\subsection{Immune gene from C. gigas gene expression in haemocytes}

The relative expression of two genes from $C$. gigas spat was studied during assays. The relative quantification value (ratio $R$ ) was calculated using the method described by Pfaffl: $R=\left[\left(E_{\text {target }}\right)^{\Delta C T}\right.$

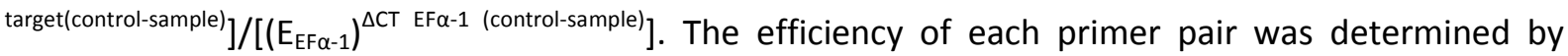
constructing a standard curve from serial dilutions. These 2 genes from the Pacific oyster were myeloid differentiation factor 88 (MyD88) and interferon-induced protein 44 (IFI44), selected based on previous studies (Renault et al., 2011, Segarra et al., 2015) showing that their expression was significantly increased during OsHV-1 infection.

\subsection{Transmission electron microscopy examination}


222 of ethanol, and treatment with 2 baths of propylene oxide, samples were progressively impregnated

223 and embedded in Epon. After polymerization at $60^{\circ} \mathrm{C}$, semi-thin sections were cut to $1-\mu \mathrm{m}$ thickness

224 for quality control and then to $80-85 \mathrm{~nm}$ for examination on Leica Ultracut (EM UC6), with the ultra-

225 thin sections floated onto copper EM grids and stained with uracil acetate/ lead citrate (Lewis and

226 Knight, 1977). The sections were examined using a transmission electron microscope (JEOL-JEM

227 1000) at $80 \mathrm{kV}$.

228

$229 \quad 3$ Results

230

2313.1 OsHV-1 DNA detection in haemocytes

233 During the in vitro assays, the quantification of OsHV-1 DNA was carried out by sampling at 1, 4, 8, 18

234 and $24 \mathrm{~h}$ after virus contact (Figure 1). Average virus DNA amounts were $3.56 \times 10^{5}$ at T0, $1.3 \times 10^{6}$ at

$2351 \mathrm{~h}, 1.5 \times 10^{6}$ at $4 \mathrm{~h}, 1.27 \times 10^{6}$ at $8 \mathrm{~h}, 2.3 \times 10^{6}$ at $18 \mathrm{~h}$ and $2.3 \times 10^{6}$ at $24 \mathrm{~h}$ viral DNA copies/ $\mu \mathrm{L}$ of

236 total DNA extracted from the haemolymph pellets assumed to represent haemocytes. Virus DNA

237 amounts at $1,4,8,18$ and $24 \mathrm{~h}$ after virus contact were significantly different T0 ( $\mathrm{p}=0.001-0.010)$.

238 The differences corresponded to an increase of virus DNA, the virus DNA quantity being 4-fold

239 greater than T0 at $4 \mathrm{~h}$ and $8 \mathrm{~h}$ and 8 -fold greater at $18 \mathrm{~h}$ and $24 \mathrm{~h}$.

240

2413.2 OsHV-1 gene expression in haemocytes 
243 OsHV-1 RNA transcripts were detected in C. gigas haemocytes (haemolymph pellets) using RT-qPCR

244 for the 15 selected viral genes. The selected ORFs are mostly involved in various known biological

245 functions, coding for apoptosis proteins (ORF42, 87, 99 and 106), enzymes (ORF 20, 57, 75 and 100),

246 ring finger proteins (ORF53 and 117), and membrane proteins (ORF 25, 72 and 80), with two others

247 corresponding to uncharacterized proteins (ORF 82 and 104). Viral mRNAs were detectable from one

248 hour after contact for all the selected viral genes. Figure 2 illustrates averaged changes in gene

249 expression by exposure time. The selected representation allows visualization of the variability of the

250 expression level of genes according to the time of exposure to the virus. Some genes were highly

251 expressed, such as ORF 80, ORF 82 or ORF 104. Others were not, like ORF 100, ORF 106 or ORF 53.

252 One, ORF 117, reached a lower peak level but did so earlier in the challenge.

253 The results of the PCA (Figure 3) showed that essential inertia of this analysis (total variance near

$25495 \%)$ was supported by axis $1(\approx 85 \%)$ and to a lesser extent by axis 2 ( $\approx 10 \%)$ (Figure 3a). Whatever

255 the exposure time, the expression level was reported by axis 1 (Figure $3 b$ ) with the highest values on

256 the left (all the arrows pointing toward the left). This axis illustrated the quantitative aspect of the

257 experiment. Axis 2 took into account the effect of exposure time: a top gradient down appeared with

258 times of exposure, weak and strong, in top and bottom, respectively.

259 Thanks to K-means analysis of the PCA outputs, previous quantitative and kinetic considerations of

260 experimental results allowed gene discriminations into 6 groups (Figure 4): (i) genes with low

261 expression expressed rather late, ORF 20, ORF 25, ORF 100 and ORF 10; (ii) genes with intermediate

262 expression expressed rather late, ORF 72, ORF 82 and ORF 104; (iii) genes with low expression

263 expressed rather early, ORF 42, ORF 53 and ORF 57; (iv) genes with intermediate expression

264 expressed rather early, ORF 75, ORF 87 and ORF 99; (v) a gene with intermediate expression

265 expressed very early, ORF 117; and (vi) a gene with high expression expressed very late, ORF 80

266 (Figure 4). 
267 In another way, Figure 5 showed relative changes of viral gene expression at each exposure time.

268 Some genes, including ORF 117, tended to be quickly expressed, from one hour, with expression

269 subsequently decreasing (Figure 5). Other genes such as ORF 82, ORF 80, ORF 72 and ORF 25 were

270 gradually expressed during the time course of the experiments. These three last ORFs, whose curves

271 presented an increase over time (in all cases up to 8 hours), were associated with membrane

272 proteins (Figure 5c). Apoptosis and enzyme genes were unchanged, they expressed at the same level

273 (figure $5 a$ and $5 b$ ).

274

275 Immune gene expression of $C$. gigas during an in vitro experiment

277 A significant increase in mRNA levels was reported for IFI44 and MyD88 at several times after

278 infection in vitro between control and haemocytes in contact with the virus (Figures 6a and 6b).

279 MyD88 gene expression was up-regulated at 4 hpi (hour post infection) in haemocytes in contact

280 with the virus $(R=9.18)$ compared to control $(R=3.8)(p<0.05)$, and at 8 hpi in haemocytes in

281 contact with the virus $(R=7.10)$ compared to control $(R=3.5)(p<0.05)$ (Figure 6a). IFI44 gene

282 expression was up-regulated at $8 \mathrm{hpi}$ in haemocytes in contact with the virus $(R=1.67)$ compared to

283 control $(R=0.56)(p<0.05)$, at 18 hpi in haemocytes in contact with the virus $(R=4.85)$ compared to

284 control $(R=0.24)(p<0.05)$, and 24 hpi in haemocytes in contact with the virus $(R=3.935)$ compared

285 to control $(R=0.35)(p<0.05)$ (Figure $6 b)$.

287 Transmission electron microscopy examination 
288 Although cell structures appeared to be well preserved (Figure 7), TEM examination did not permit 289 the identification of viral capsids and enveloped particles in haemocytes $18 \mathrm{~h}$ and $24 \mathrm{~h}$ after virus 290 contact.

\section{Discussion}

294 The objective of the present work was to study if OsHV-1 is able to penetrate and initiate viral 295 replication in haemocytes following in vitro contact with the virus.

296 In this context, in vitro assays were undertaken putting haemocytes in contact with a viral suspension 297 to better understand the potential role of these cells in infection with OsHV-1. It was chosen to work 298 under in vitro conditions using circulating cells collected from haemolymph to avoid complex 299 interactions. The protocol previously developed by Renault et al. (2011) was adapted and modified. 300 In vitro viral contact assays were performed over a 24-hour period. In the course of these in vitro 301 assays a quantification of the viral DNA was carried out and the expression of viral genes was 302 assessed according to the work of Segarra et al. (2014a) and Martenot et al., (2017). Moreover, 303 observations by transmission electron microscopy were carried out in order to research viral 304 particles.

305 The results showed an increase of the amounts of viral DNA over time, beginning by $1 \mathrm{~h}$ post virus 306 contact and becoming even more significant at $18 \mathrm{~h}$ and $24 \mathrm{~h}$. Associated with these results was the 307 detection of the viral transcripts as soon as $1 \mathrm{~h}$ after virus contact with an increase in viral transcripts 308 over time. The association of viral DNA and RNA in cells collected from haemolymph suggested that 309 the virus replicated in haemocytes. However, differences in terms of viral transcript amounts varied 310 depending of the analyzed ORFs. 
311 During their productive cycle, vertebrate herpesviruses exhibit a strictly regulated temporal cascade

312 of gene expression that can be divided into three main stages: immediate-early (IE), early (E), and 313 late (L). Herpesvirus genes have traditionally been classified kinetically on the basis of individual 314 expression studies in cell cultures (Honess et al., 1974). Different studies have been performed to 315 define the expression of early and/or late genes and contributed to the classification and functional characterization of viral genes. Genome-wide microarray and reverse transcription quantitative (RT-

317 q)PCR expression studies have been performed for several mammalian herpesviruses belonging to 318 the family Herpesviridae (Stingley et al., 2000, Martinez-Guzman et al., 2003, Dittmer et al., 2005, 319 Tombácz et al., 2009, Wagner et al., 2002, Ebrahimi et al., 2003, Aguilar et al., 2005, Aguilar et al., 320 2006). In channel catfish virus (ictalurid herpesvirus 1, IcHV1) the expression kinetics of a limited 321 number of open reading frames (ORFs), namely ORF3, ORF5, ORF5/6, ORF6, ORF8A/9, ORF9, 322 ORF12/13, ORF39 and ORF46 (Huang et al., 1998, Silverstein et al., 1998, Silverstein et al., 1995), has 323 been studied in cell culture by northern blot analyses. Transcriptional regulation of the 14 ORFs in 324 the terminal direct repeat of the genome has also been analyzed by northern blot analysis in cell 325 culture (Stingley et al., 2000) and in vivo (Stingley et al., 2003). For this small number of IcHV1 ORFs, temporal expression patterns similar to that of mammalian herpesviruses were demonstrated. In 327 addition, transcription in cell culture of 20 ORFs in koi herpesvirus (cyprinid herpesvirus 3, CyHV3) was demonstrated by RT-PCR (Dishon et al., 2007). Segarra et al (2014a) initiated some work in this field, assessing the transcription of 39 OsHV-1 genes during experimental in vivo infections. Although

330 a few of genes were expressed early after virus injection, it remained difficult to define clear kinetics 331 of virus gene expression (Segarra et al., 2014a; 2014b). Such results could be due to the use of the 332 mantle to assess viral gene expression. The cells of this organ could be infected non-concomitantly, 333 obscuring the dynamics of the virus cycle. Indeed, cell lines are generally used to monitor replication 334 of the virus under in vitro conditions (Beurden et al., 2013), but there are no bivalve cell lines. In this 335 context, haemocytes that can be easily collected from haemolymph can be of interest to decipher 
336 the viral cycle and kinetics of viral gene expression keeping in mind that those could be different 337 depending of cell types.

338 Although haemocytes and haemolymph were considered to play a role in the development of OsHV3391 infection in Pacific oysters by some authors (Schikorsky et al., 2012b, Segarra et al., 2015, Segarra 340 et al., 2016), replication of OsHV-1 has never been demonstrated in haemocytes, the oyster defense 341 cells. Segarra et al. (2016) hypothesized that the virus could be transported by haemocytes because, 342 using in situ hybridization, they observed strong labelling in the heart and the haemolymphatic 343 system with positive cells interpreted to be haemocytes, which could suggest a place of replication 344 and dissemination of the virus through the haemolymphatic system to all compartments of the 345 oyster. Similarly, the first transcriptomic work carried out on $C$ gigas and OsHV-1 was performed 346 between haemocytes and the virus (Renault et al., 2011). The results obtained made it possible to 347 show for the first time immune genes involved in the response to OsHV-1 infection. These genes 348 have since been widely used as markers of OsHV-1 infection (Green et al., 2014a, Green et al., 2015, 349 Segarra et al 2014b).

350 The expression levels of two host genes, Myeloid differentiation 88 (MyD88) and Interferon induced 351 protein 44 (IFI44) genes, were also analyzed during the in vitro assays. It was previously shown that the expression of these genes was modulated in C. gigas haemocytes after a contact with OsHV-1 (Renault et al., 2011). MyD88 transcripts were up-regulated at $4 \mathrm{~h}$ and $8 \mathrm{~h}$. Segarra et al. (2014b) 354 showed that the expression level of MyD88 was positively correlated with viral DNA amounts. IFI44 was highly up-regulated at $8 \mathrm{hpi}$ and continued to increase at $24 \mathrm{hpi}$. The detection of increasing levels of IFI44 transcripts in infected haemocytes was thus concomitant with the detection of increasing amounts of OsHV-1 DNA and RNA by real-time PCR. As previously reported by Renault et al (2011) and Segarra et al. (2014b), expression of the MyD88 and IFI44 genes was enhanced in the present 359 work confirming that these genes are markers of interest with regard to viral infection. It should be 360 recalled that Segarra et al (2014b) proposed that if the overexpression of the MyD88 gene could 
361 have a negative prognostic value (a high level of transcripts is associated with high mortality rates

362 under experimental conditions), that of the gene IFI44 rather seemed associated with a real ability to 363 defend against the viral infection.

364 A principal component analysis was undertaken to demonstrate whether there was a differential 365 expression of viral genes over time. Differential expression level was reported. ORF 117, encoding an 366 unknown protein, was expressed very early and then its level of expression decreased. Conversely, a 367 weak expression of the ORF 80 (encoding a putative membrane protein) was reported early after 368 virus contact although a very strong expression was observed after $18 \mathrm{~h}$ and $24 \mathrm{~h}$. Comparable to 369 mammalian and fish herpesviruses, most of the early and early-late genes encode proteins involved 370 in viral DNA replication, enzymes involved in nucleic acid metabolism (Beurden et al., 2013). Most of 371 the late genes encode structural proteins such as membrane proteins, capsid proteins and 372 glycoproteins (Stingley et al 2003, DeeAnn Martinez-Guzman et al., 2003). However in 373 Gammaherpesvirus, Martinez-Guzman et al.(2003) showed that one glycoprotein and one tegument 374 protein peaked relatively early at $8 \mathrm{hpi}$ and remained high.

375 Although viral DNA and RNA detection suggested that viral replication occurred in oyster haemocytes 376 maintained in vitro, transmission electron microscopic examination did not result in identification of 377 viral particles. From these results several questions arise. Is the virus able to produce complete viral 378 particles in haemocytes? There can be not an expression of all ORFs which results in an incomplete 379 viral cycle in this cell type, and that opens new questions on the role of the haemocyte (persistence 380 or productive cycle). OsHV-1 infection of oyster haemocytes may result in an abortive infection, with 381 no viral particle production, as occurs when MDV or HSV-1 infects macrophages (Morahan et al., 382 1989; Tenney \& Morahan, 1991; Barrow et al., Wu et al., 1993; Barrow et al. 2003). Does the 383 complete viral replication occur only in a very small number of cells rendering the observation of viral 384 particles quite hazardable? 


\section{Conclusion}

389 For the first time, we have shown that a virus can initiate viral replication in haemocytes following an

390 in vitro contact. We also studied kinetics of expression of some viral genes using RT-qPCR. The results

391 showed that there were differential patterns of expression of viral genes over time. One gene, ORF

392 117, was identified as very early expressed, other genes as intermediately expressed. A gene with a

393 high level of expression, represented by ORF 80, was expressed quite late. These results showed that

394 OsHV-1 gene transcription is effective in Pacific oyster haemocytes maintained in in vitro conditions.

395 Our results open new ways of research in order to explore OsHV-1 pathogenesis. First, haemocytes

396 are critical to innate immunity and the virus evolved to perturb host defence. Second, and as

397 hypothesized previously (Segarra et al., 2016), haemocytes are excellent candidate cells for

398 transporting OsHV-1 to target organs including mantle and gills during the earliest stages of 399 pathogenesis. Haemocytes could be 'carrier cells' responsible for transporting OsHV-1 to target 400 organs such as heart, mantle, and gills during the earliest stages of pathogenesis. Third, in vitro 401 infection could be used to determine the kinetic of the viral gene during his replication using a global 402 approach using the NGS sequencing.

\section{Acknowledgments}

405 The authors wish to thank the Ifremer hatchery team (LGPMM) in La Tremblade and the nursery 406 team (LSPC) in Bouin for the production of Pacific oysters. Sandy Picot and Claire Martenot are 407 thanked for their technical support. The authors are very grateful to Dr. Ryan Carnegie and Dr. Claire 408 Martenot for revising the manuscript. This work received financial support from the European 
409 projects VIVALDI (H2020 $\left.\mathrm{n}^{\circ} 678589\right)$ and from the Ifremer's Scientific Direction (Projet direction 410 scientifique) and the EU funded project.

411 
Aguilar, J.S., Ghazal, P., Wagner, E.K., 2005. Design of a herpes simplex virus type 2 long oligonucleotide-based microarray: global analysis of HSV-2 transcript abundance during productive infection. Methods Mol. Biol. 292, 423-448.

Aguilar, J.S., Devi-Rao, G.V., Rice, M.K., Sunabe, J., Ghazal, P., Wagner, E.K., 2006. Quantitative comparison of the HSV-1 and HSV-2 transcriptomes using DNA microarray analysis. Virology 348, 233-241. http://dx.doi.org/10.1016/j.virol.2005.12.036.

Arzul, I., Renault, T., Lipart, C., 2001a. Experimental herpes-like viral infections in marine bivalves: demonstration of interspecies transmission. Dis. Aquat. Organ. 46, 1-6. http://dx.doi.org/10.3354/dao046001.

Arzul, I., Renault, T., Lipart, C., Davison, A.J., 2001b. Evidence for interspecies transmission of oyster herpesvirus in marine bivalves. J. Gen. Virol., 82, 865-870.

Arzul, I., Renault, T., Thébault, A., Gérard, A., 2002. Detection of oyster herpesvirus DNA and proteins in asymptomatic Crassostrea gigas adults. Virus Res. 84, 151-160. http://dx.doi.org/10.1016/S0168-1702(02)00007-2.

Barrow, A.D., Burgess, S.C.., Baigent, S.J., Howes, K., Nair, V.K., 2003. Infection of macrophages by a lymphotropic herpesvirus: a new tropism for Marek's disease Virus. J. Gen. Virol., 84, 2635-2645. http://dx.doi.org/10.1099/vir.0.1920660.

van Beurden, S.J., Peeters, B.P., Rottier, P.J., Davison, A.J., Engelsma, M.Y., 2013. Genomewide gene expression analysis of anguillid herpesvirus 1. BMC Genomics 6, 14:83. http://dx.doi.org/1471-2164/14/83.

Corbeil, S., Faury, N., Segarra, A., Renault, T. 2015. Development of an in situ hybridization assay for the detection of ostreid herpesvirus type 1 mRNAs in the Pacific oyster, Crassostrea gigas. J. Virol. Methods 211, 43-50. http://dx.doi.org/10.1016/j.jviromet.2014.10.007.

Davison, A.J., Eberle, R., Ehlers, B., Hayward, G.S., McGeoch, D.J., Minson, A.C., Pellett, P.E., Roizman, B., Studdert, M.J., Thiry, E., 2009. The order Herpesvirales. Arch. Virol. 154, 171177. http://dx.doi.org/10.1007/s00705-008-0278-4.

Davison, A.J., Trus, B.L., Cheng, N., Steven, A.C., Watson, M.S., Cunningham, C., Le Deuff, R.M., Renault, T., 2005. A novel class of herpesvirus with bivalve hosts. J. Gen. Virol. 86, 4153. http://dx.doi.org/10.1099/vir.0.80382-0.

Dishon, A., Davidovich, M., Ilouze, M., Kotler, M., 2007. Persistence of cyprinid herpesvirus 3 in infected cultured carp cells. J. Virol. 81, 4828-4836. http://dx.doi.org/10.1128/JVI.0218806.

Dittmer, D.P., Gonzalez, C.M., Vahrson, W., DeWire, S.M., Hines-Boykin, R., Damania, B., 2005. Whole-genome transcription profiling of rhesus monkey rhadinovirus. J. Virol. 79 (13): 8637-8650. 10.1128/JVI.79.13.8637-8650.2005. 
Ebrahimi, B., Dutia, B.M., Roberts, K.L., Garcia-Ramirez, J.J., Dickinson, P., Stewart, J.P., Ghazal, P., Roy, D.J., Nash, A.A., 2003. Transcriptome profile of murine gammaherpesvirus-68 lytic infection. J. Gen. Virol. 84, 99-109. http://dx.doi.org/10.1099/vir.0.18639-0.

Efsa, 2015. Oyster mortality 13(6), 4122 (p. 59). http://dx.doi.org/10.2903/j.efsa. 2015.4122.

Fisher, W.S., 1986. Structure and functions of oyster hemocytes, in: Brehélin D.M. (Ed.), Immunity in Invertebratres., Springer, Berlin Heidelberg, pp. 25-35.

Green, T.J., Benkendorff, K., Robinson, N., Raftos, D., Speck, P. 2014a. Anti-viral gene induction is absent upon secondary challenge with double-stranded RNA in the Pacific oyster, Crassostrea gigas. Fish Shellfish Immunol. 39, 492-497. http://dx.doi.org/10.1016/j.fsi.2014.06.010.

Green, T.J., Robinson, N., Chataway, T., Benkendorff, K., O'Connor, W., Speck P., 2014b. Evidence that the major hemolymph protein of the Pacific oyster, Crassostrea gigas, has antiviral activity against herpesviruses. Antiviral Res. 110, 168-174. http://dx.doi.org/10.1016/j.antiviral.2014.08.010.

Green, T. J., Rolland, J-L., Vergnes, A., Raftos, D., Montagnani ,C., 2015. OsHV-1 countermeasures to the Pacific oyster's anti-viral response. Fish \& Shellfish Immunology, 47(1), 435-443 . http://doi.org/10.1016/i.fsi.2015.09.025,

Honess, R.W., Roizman, B., 1974. Regulation of herpesvirus macromolecular synthesis, I. Cascade regulation of the synthesis of three groups of viral proteins. J. Virol. 14, 8-19.

Huang, S., Hanson, L.A., 1998. Temporal gene regulation of the channel catfish virus (Ictalurid herpesvirus 1). J. Virol. 72, 1910-1917.

Jenkins, C., Hick, P., Gabor, M., Spiers, Z., Fell, S.A., Gu, X., Read, A., Go, J., Dove, M., O'Connor, W., Kirkland, P.D., Frances, J., 2013. Identification and characterisation of an ostreid herpesvirus-1 microvariant (OsHV-1 $\mu$-var) in Crassostrea gigas (Pacific oysters) in Australia. Dis. Aquat. Organ. 105, 109-126. http://dx.doi.org/10.3354/dao02623.

Keeling, S.E., Brosnahan, C.L., Williams, R., Gias, E., Hannah, M., Bueno, R., McDonald, W.L., Johnston, C., 2014. New Zealand juvenile oyster mortality associated with ostreid herpesvirus 1-an opportunistic longitudinal study. Dis. Aquat. Organ. 109, 231-239. http://dx.doi.org/103354/dao02735.

Le Deuff, R.M., Renault, T., 1999. Purification and partial genome characterization of a herpes-like virus infecting the Japanese oyster, Crassostrea gigas. J. Gen. Virol. 80, 13171322.

Lipart, C., Renault, T., 2002. Herpes-like virus detection in infected Crassostrea gigas spat using DIG-labelled probes. J. Virol. Methods 101, 1-10. 
Martenot, C., Segarra, A., Baillon, L., Faury, N., Houssin, M., Renault, T. 2016. In situ localization and tissue distribution of ostreid herpesvirus 1 proteins in infected Pacific oyster, Crassostrea gigas. J. Invertebr. Pathol. 136, 124-135. http://doi.org/10.1016/j.jip.2016.04.002.

Martenot, C., Gervais, O., Chollet, B., Houssin, M., Renault, T., 2017. Haemocytes collected from experimentally infected Pacific oysters, Crassostrea gigas: Detection of ostreid herpesvirus 1 DNA, RNA, and proteins in relation with inhibition of apoptosis. Plos One, 12(5), e0177448 (1-19) . http://doi.org/10.1371/journal.pone.0177448

Martinez-Guzman, D., Rickabaugh, T., Wu, T.T., Brown, H., Cole, S., Song, M.J., Tong, L., Sun, R., 2003. Transcription program of murine gammaherpesvirus 68. J. Virol. 77, 10488-503.

Morahan, P.S., Mama, S., Anarki, F., Leary, K., 1989. Molecular localization of abortive infection of resident peritoneal macrophages by herpes simplex virus type 1. J. Virol. 63, 2300-2307.

Paul-pont, I., Dhand, N.K., Witthington, R.J., 2013. Influence of husbandry practices on OsHV1 associates mortality of Pacific oysters Crassostrea gigas. Aquaculture 412-413, 202-214. http://dx.doi.org/10.1016/j.aquaculture.2013.07.038.

Paul-pont, I., Evans, O., Dhand, N.K., Rubio, A., Coad, P., Whittington, R.J., 2014. Descriptive epidemiology of mass mortality due to Ostreid herpesvirus-1 (OsHV-1) in commercially farmed Pacific oysters (Crassostrea gigas) in the Hawkesbury River estuary, Australia. Aquaculture 422-423. http://dx.doi.org/10.1016/j.aquaculture.2013.12.009.

Renault, T., 2012. Pacific Cupped Oyster, Crassostrea gigas, Mortality Outbreaks and Infectious Disease, in: Qin, J.G. (Ed.), Oysters Physiology, Ecological distribution and Mortality. Nova Science Publishers Inc., New York, pp. 203-225.

Renault, T., Lipart, C., Arzul, I., 2001. A herpes-like virus infecting Crassostrea gigas and Ruditapes philippinarum larvae in France. J. Fish Dis. 24, 369-376. http://dx.doi.org/10.1046/j.1365-2761.2001.00300.x.

Renault, T., Moreau, P., Faury, N., Pepin, J.F., Segarra, A., Webb, S., 2012. Analysis of clinical Ostreid herpesvirus 1 (Malacoherpesviridae) specimens by sequencing amplified fragments from three virus genome areas. J. Virol. 86, 5942-5947. http://dx.doi.org/10.1128/JVI.06534$\underline{11 .}$

Renault, T., Faury, N., Barbosa-Solomieu, V., Moreau, K., 2011. Suppression substractive hybridisation (SSH) and real time PCR reveal differential gene expression in the Pacific cupped oyster, Crassostrea gigas, challenged with Ostreid herpesvirus 1. Dev. Comp. Immunol. 35, 725-735. http://dx.doi.org/10.1016/j.dci.2011.02.004.

Schikorski, D., Faury, N., Pepin, J.F., Saulnier, D., Tourbiez, D., Renault, T., 2011 . Experimental ostreid herpesvirus 1 infection of the Pacific oyster Crassostrea gigas: kinetics of virus DNA detection by q-PCR in seawater and in oyster samples. Virus Res. 155, 28-34. http://dx.doi.org/10.1016/j.virusres.2010.07.031. 
553 Schikorski, D., Renault, T., Saulnier, D., Faury, N., Moreau, P., Pepin, J., 2011b. Experimental 554 infection of Pacific oyster Crassostrea gigas spat by ostreid herpesvirus 1: demonstration of

555

556

557

558

559

560

561

562

563

564

565

566

567

568

569

570

571

572

573

574

575

576

577

578

579

580

581

582

583

584

585

586

587

588

589

590

591

592

593

594

595

596

597 oyster spat susceptibility. Vet. Res. 42, 27. http://dx.doi.org/10.1186/1297-9716-42-2

Segarra, A., Pépin, J.F., Arzul, I., Morga, B., Faury, N., Renault, T., 2010. Detection anddescription of a particular Ostreid herpesvirus 1 genotype associated with massive mortality outbreaks of Pacific oysters, Crassostrea gigas, in France in 2008. Virus Res. 153, 92-99. http://dx.doi.org/10.1016/j.virusres.2010.07.011.

Segarra, A., Baillon, L., Faury, N., Tourbiez, D., Renault, T., 2016. Detection and distribution of ostreid herpesvirus 1 in experimentally infected Pacific oyster spat. J. Invertebr. Pathol. 133, 59-65. http://dx.doi.org/10.1016/j.jip.2015.11.013.

Segarra, A., Faury, N., Pepin, J.F., Renault, T. 2014a. Transcriptomic study of 39 ostreid herpesvirus 1 genes during an experimental infection . J. Invertebr. Pathol. 119, 5-11. http://dx.doi.org/10.1016j.jip.2014.03.02.

Segarra, A., Mauduit, F., Faury, N., Trancart, S., Dégremont, L., Tourbiez, D., Haffner, P., Barbosa-Solomieu, V., Pépin, J.F., Travers, M.A., Renault, T. 2014b. Dual transcriptomics of virus-host interactions: comparing two Pacific oyster families presenting contrasted susceptibility to ostreid herpesvirus 1 . Bmc Genomics , 15, 1-13. http://dx.doi.org/10.1186/1471-2164-15-580.

Segarra, A., Faury, N., Pépin, J.F., Renault, T., 2014. Transcriptomic study of 39 ostreid herpesvirus 1 genes during an experimental infection. J. Invertebr. Pathol. 119, 5-11. http://dx.doi.org/10.1016/j.jip.2014.03.002.

Silverstein, P.S, Bird, R.C, van Santen, V.L, Nusbaum, K.E, 1995. Immediate-early transcription from the channel catfish virus genome: characterization of two immediate-early transcripts. J. Virol. 69, 3161-3166.

Silverstein, P.S., van Santen, V.L., Nusbaum, K.E., Bird, R.C., 1998. Expression kinetics and mapping of the thymidine kinase transcript and an immediate-early transcript from channel catfish virus. J. Virol. 72, 3900-3906.

Stingley, R.L., Gray, W.L., 2000. Transcriptional regulation of the channel catfish virus genome direct repeat region. J. Gen. Virol. 81, 2005-2010. http://dx.doi.org/10.1099/00221317-81-8-2005

Stingley, R.L., Griffin, B.R., Gray, W.L., 2003. Channel catfish virus gene expression in experimentally infected channel catfish, Ictalurus punctatus (Rafinesque). J. Fish Dis. 26, 487493. $h t t p: / / d x . d o i . o r g / 10.1046 / j .1365-2761.2003 .00484$.

Stingley, S.W., Ramirez, J.J., Aguilar, S.A., Simmen, K., Sandri-Goldin, R.M., Ghazal, P., Wagner, E.K., 2000. Global analysis of herpes simplex virus type 1 transcription using an 
598 oligonucleotide-based DNA microarray. J. Virol. 74, 9916-9927.

599 http://dx.doi.org/10.1128/JVI.74.21.9916-9927.2000.

600

601 Tenney, D.J., Morahan, P.S., 1991. Differentiation of the U937 macrophage cell line removes

602 an early block of HSV-1 infection. Viral Immunol. 4, 91-102.

603

604 Tombácz, D., Tóth, J.S., Petrovszki, P., Boldogkoi, Z., 2009. Whole-genome analysis of 605 pseudorabies virus gene expression by real-time quantitative RT-PCR assay. BMC Genomics, 606 10, 491-10. http://dx.doi.org/10.1186/147162164-10-491.

607

608 Wagner, E.K., Ramirez, J.J., Stingley, S.W., Aguilar, S.A., Buehler, L., Devi-Rao, G.B., Ghazal, 609 P., 2002. Practical approaches to long oligonucleotide-based DNA microarray: lessons from 610 herpesviruses. Prog. Nucleic Acid Res. Mol. Biol. 71, 445-491.

611

612 Wu, L., Morahan, P.S., Leary, K., 1993. Regulation of herpes simplex virus type 1 gene 613 expression in nonpermissive murine resident peritoneal macrophages. J. Leukoc. Biol. 53, 614 61-65.

615

616

617 
619 Table 1: List of primer for viral gene expression

\begin{tabular}{|c|c|c|c|c|c|}
\hline ORFs & Forward & Reverse & $\begin{array}{c}\text { Efficiency } \\
(\%)\end{array}$ & $\begin{array}{c}\text { Amplicon } \\
\text { (bp) }\end{array}$ & Protein \\
\hline ORF20 & ctggctgttctgccatttcc & agacagcggcaaggtgatgt & 97.8 & 213 & Ribonucleotide reductase small subunit \\
\hline ORF25 & ctcgccaaaggtcgtatcca & ccacaagggtgaattccatgtt & 98.7 & 200 & Membrane protein \\
\hline ORF42 & gcaggcataacaggtgagca & tgagaggcgtgacagggaat & 99.9 & 205 & Apoptosis inhibitor \\
\hline ORF53 & ccgaaaaaccagggactgga & tgggcgggaagtagatcgtt & 98.5 & 197 & Ring finger protein \\
\hline ORF57 & ttaccagcaccgagcaggat & tcgccgcttttatccaacac & 99.2 & 150 & chloride channel \\
\hline ORF72 & acctccccgtcaatggtatga & tccaccacacccctacaatca & 94.7 & 180 & Membrane protein \\
\hline ORF75 & atgatctgcgccactctggt & tgtgcctgaaggatgtgcaa & 100 & 186 & dUTPase (Enzyme) \\
\hline ORF80 & aagaggatttgggtgcacag & ttgcatcccaggattatcag & 98.5 & 166 & Membrane protein \\
\hline ORF82 & atgcagaccaccatgtttga & ccgagagccttaacaccaag & 99 & 200 & Unknown \\
\hline ORF87 & cacagacgacatttccccaaa & aaagctcgttcccacattggt & 98.7 & 196 & Apoptosis inhibitor \\
\hline ORF99 & ggtggaggtggctgttgaaa & ccgactgacaacccatggac & 96.3 & 200 & Apoptosis inhibitor \\
\hline ORF100 & accaggaccacgcctttgat & cccgcctttccataaattgg & 100.6 & 197 & DNA polymerase \\
\hline ORF104 & gggagagcttagggaaatgg & atttaccttcgggagccact & 100.5 & 158 & Unknown \\
\hline ORF106 & tctggcatccaacctccaaa & tcagcctatgacgaggcaatg & 100.8 & 200 & Putative apoptosis inhibitor \\
\hline ORF117 & aatttcccgcctctgtgctt & tgatgacggaagtggcaaca & 98 & 200 & Ring finger protein \\
\hline
\end{tabular}

620

621 


\section{Figure caption}

624 Figure 1; Histogram of copy number of viral DNA OsHV-1 at different times of sampling 1, 4, 8, 18 and $62524 \mathrm{~h}$ post inoculation. The significant differences between the TO and the others times are shown by $626 \star(\star$ for $p=0.01$ and $\star \star$ for $p=0.001)$.

627 Figure 2 ; Heatmap of viral gene expression in haemocytes after an in vitro infection.

629 Figure 3 ; PCA on expressions of viral RNA OsHV-1 from the Pacific oyster hemocytes after different 630 times of exposure to the virus chart of eigenvalues (a) of variable representation, different exposure 631 times haemocyte virus (b).

633 Figure 4 ; Qualitative and kinetic discrimination of genes expression into 6 groups by the method of k634 means (of the result sets PCA).

636 Figure 5 ; Evolution of relative gene expression at different exposure times. (5a) Apoptosis genes, 637 (5b) Enzyme genes, (5c) Membrane genes, (5d) Ring-fingers genes, (5e) Unknown genes

639 Figure 6 ; Relative expression of immune gene of C. gigas. 6a MyD88 expression in infected 640 haemocyte. 6b IFI44 expression in infected haemocyte. The significant differences between the 641 control and infected haemocytes at each time $\star$ ( $\star$ for $p=0.01$ and $\star \star$ for $p=0.001$ ).

643 Figure 7 ; Infected haemocyte from C. gigas observed after 24 h of contact with OsHV-1 by 644 transmission electron microscopy.

645

646 Table 1: List of primer for viral genes expression 


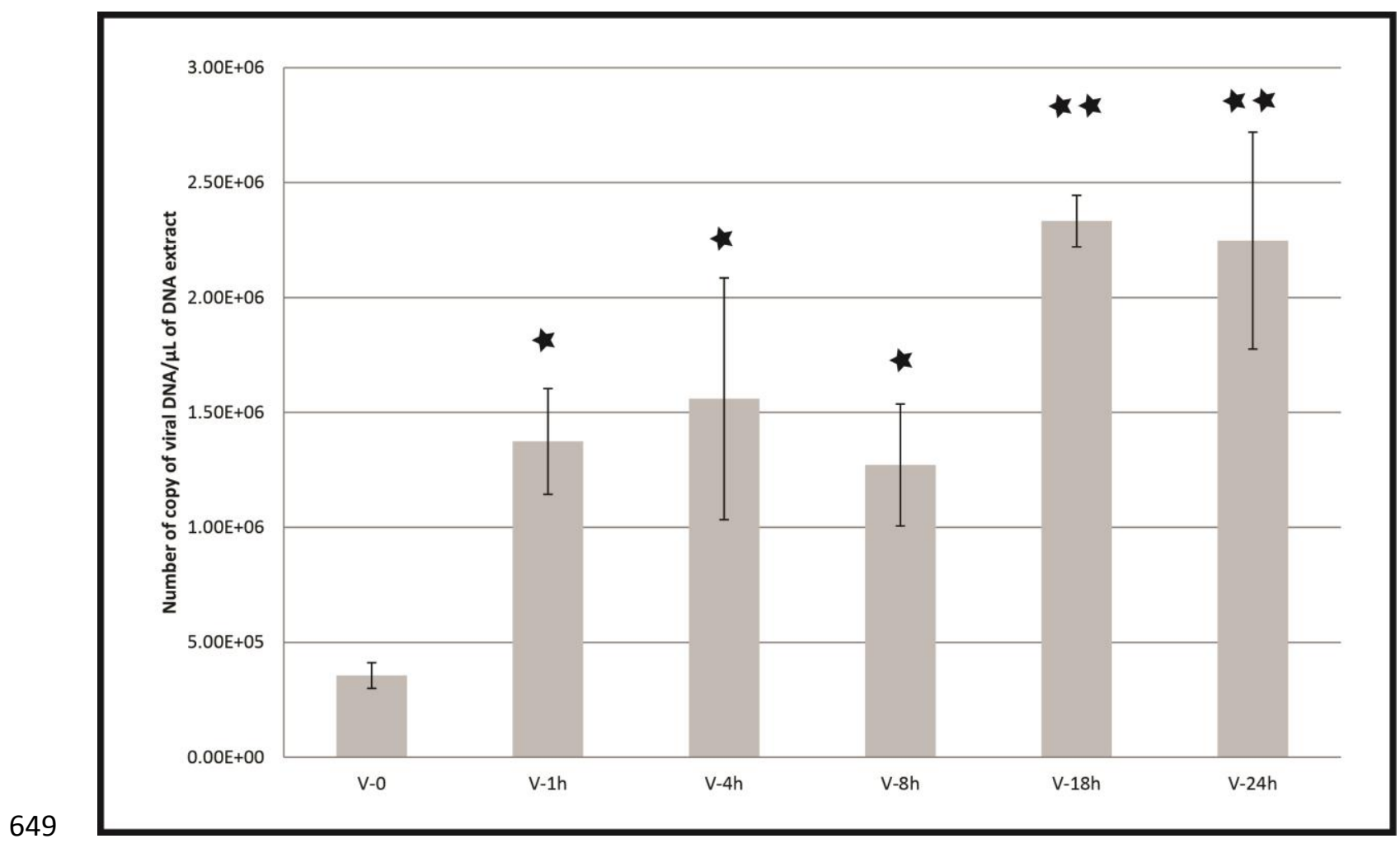

$650 \quad$ Figure 1

651 
652

\begin{tabular}{|l|l|l|l|l|l|}
\cline { 2 - 5 } \multicolumn{1}{c|}{1} & 4 & 8 & 18 & 24 \\
\hline ORF_20 & & & & & \\
\hline ORF_25 & & & & & \\
\hline ORF_42 & & & & & \\
\hline ORF_53 & & & & & \\
\hline ORF_57 & & & & & \\
\hline ORF_72 & & & & & \\
\hline ORF_75 & & & & & \\
\hline ORF_80 & & & & & \\
\hline ORF_82 & & & & & \\
\hline ORF_87 & & & & & \\
\hline ORF_99 & & & & & \\
\hline ORF_100 & & & & & \\
\hline ORF_104 & & & & & \\
\hline ORF_106 & & & & & \\
\hline ORF_117 & & & & & \\
\hline
\end{tabular}

653 Figure 2

654 


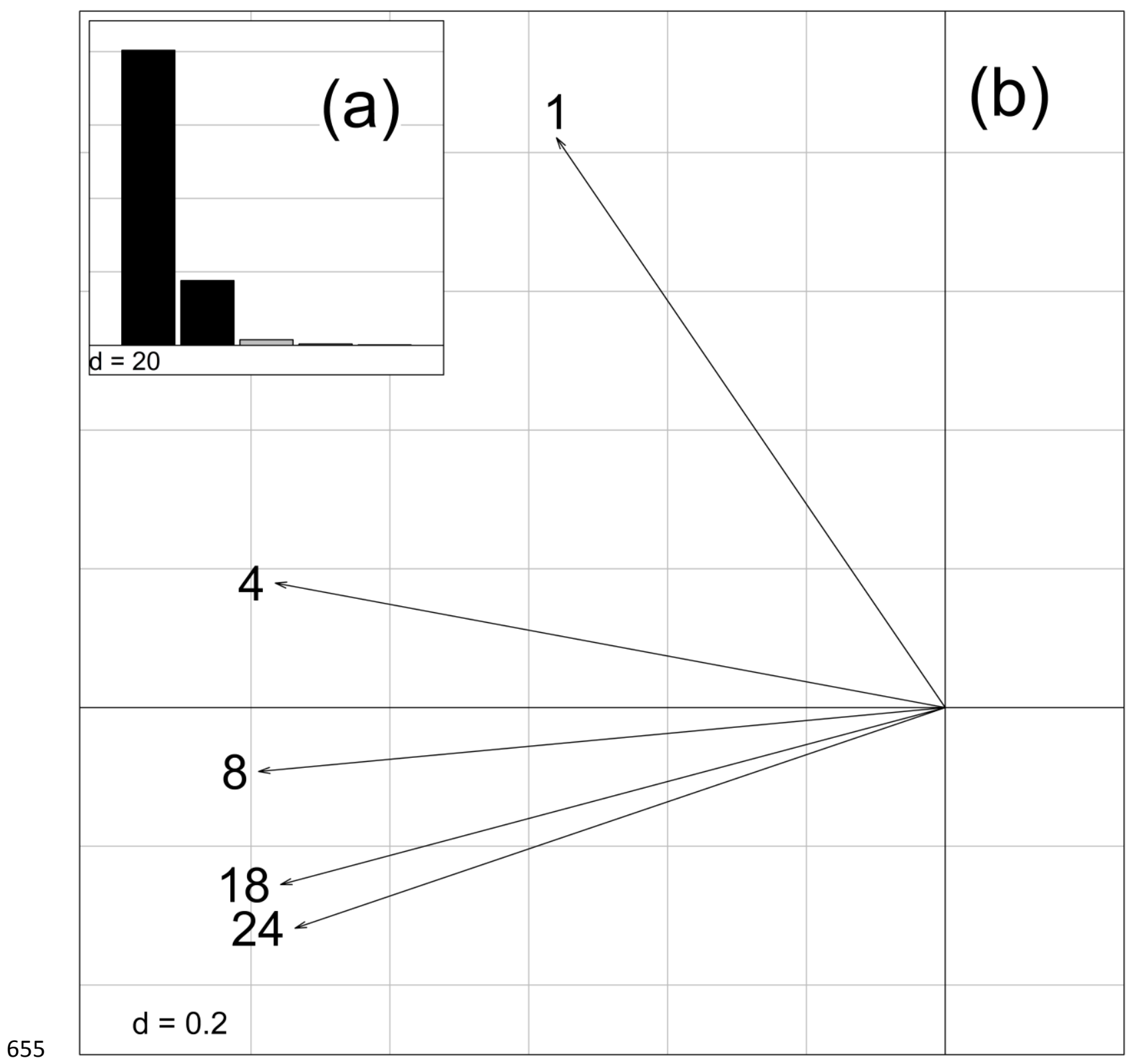

656 Figure 3

657 


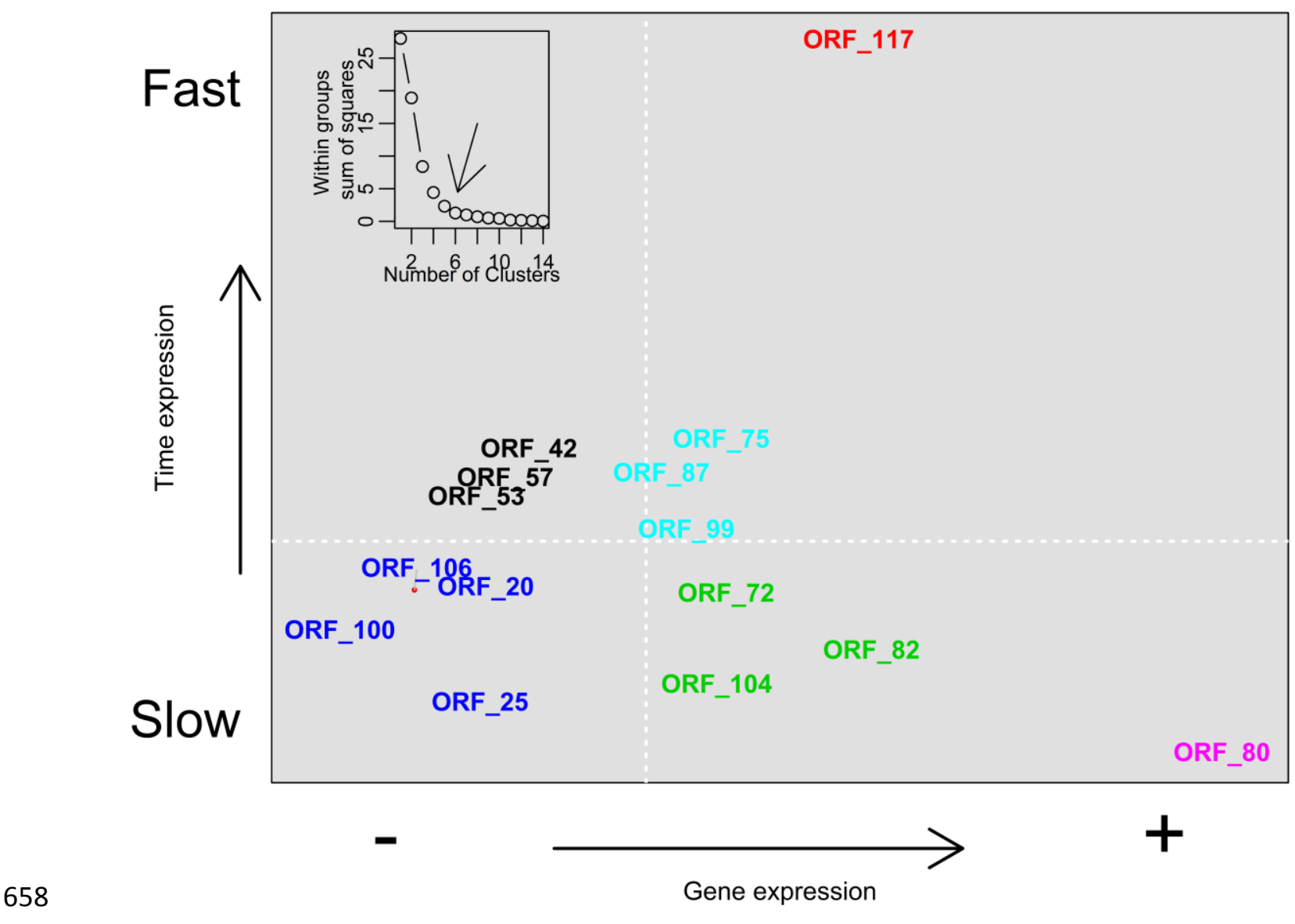

659 Figure 4

660 

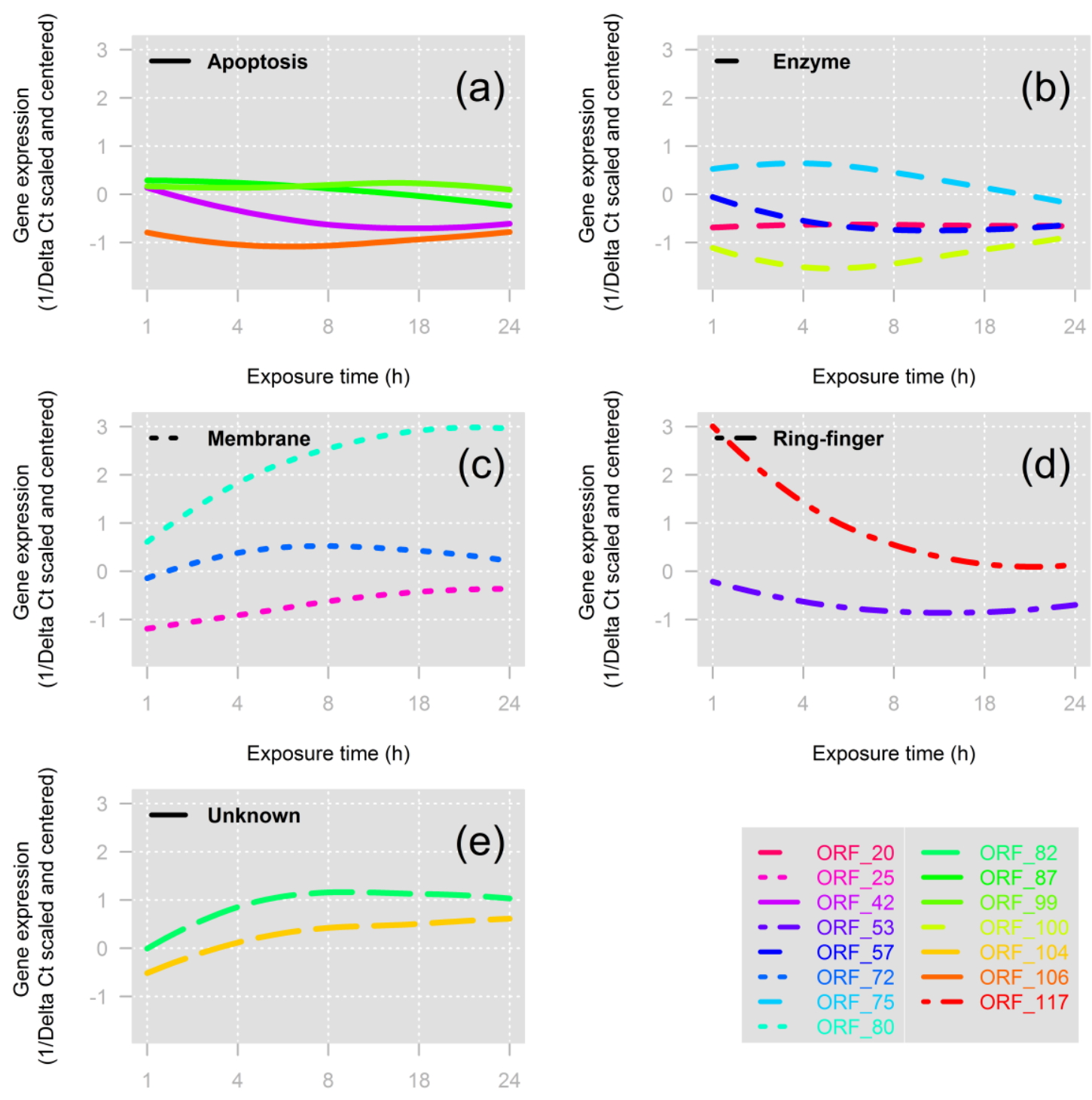

Exposure time (h)

Figure 5 


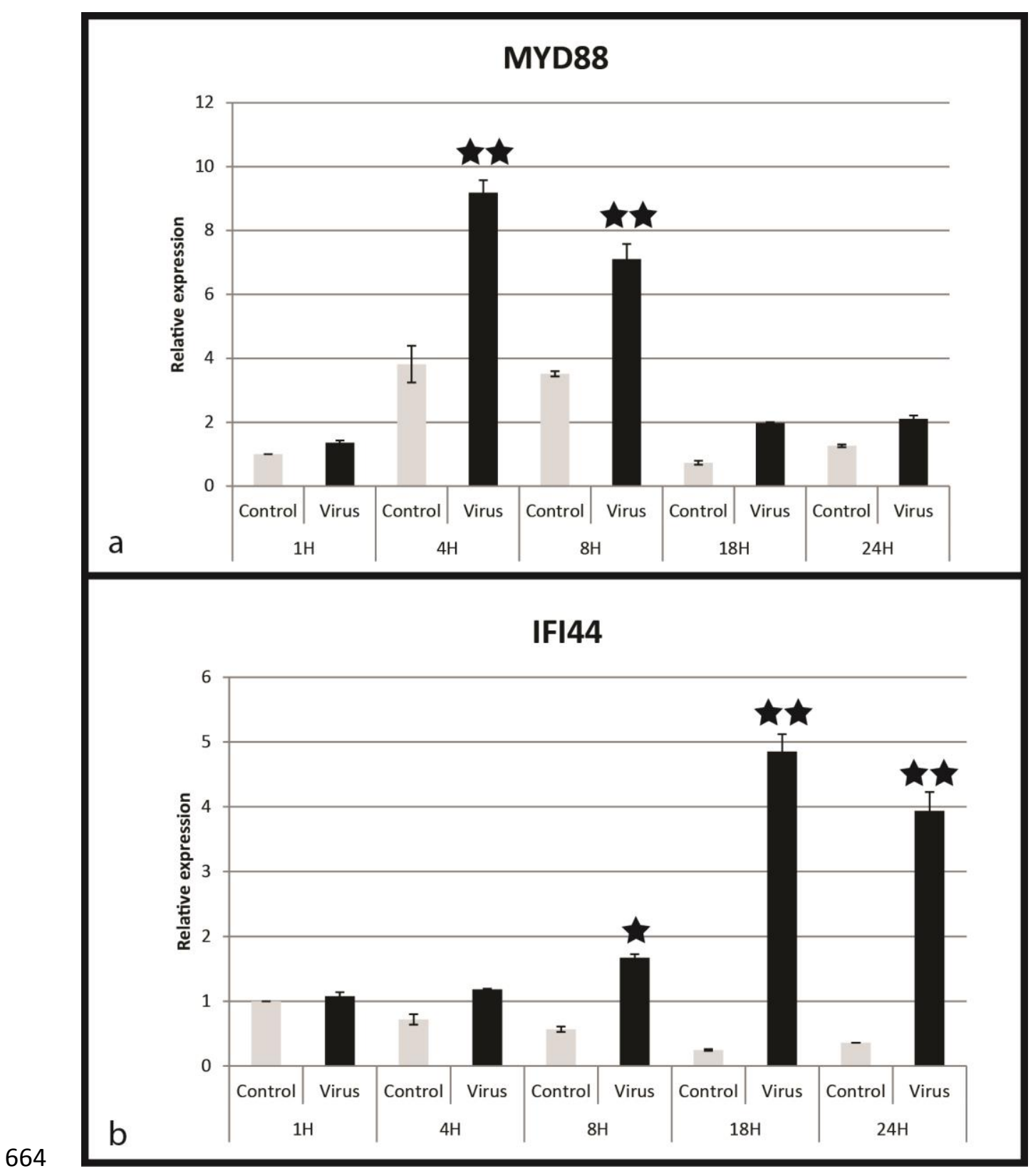

Figure 6 

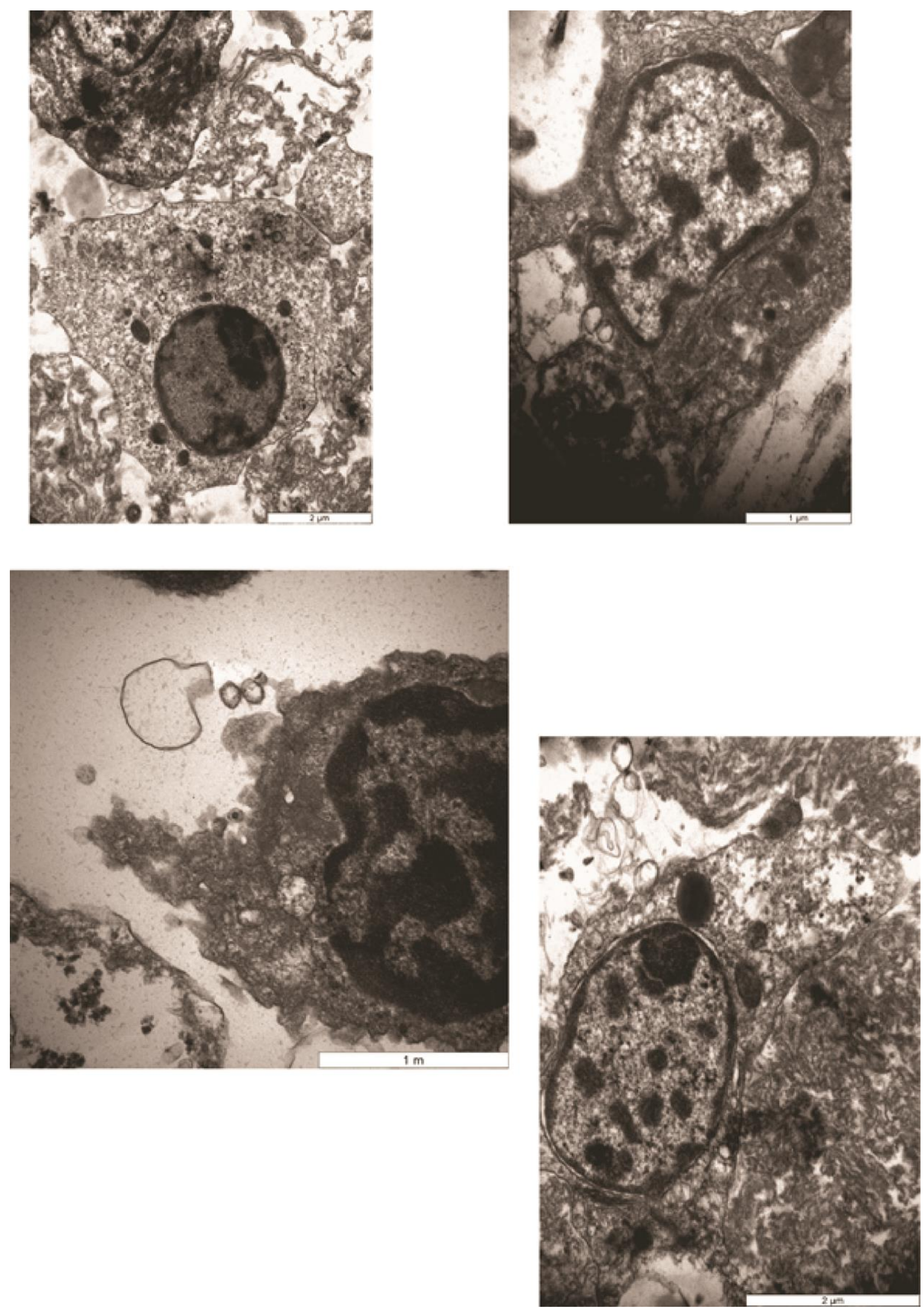

668 Figure 7 